\title{
The Impact of Appeals on the Parliamentary Elections in Jordan
}

\author{
Taha Atiyyat ${ }^{1}$ \\ ${ }^{1}$ Department of Comparative Law, Faculty of Sheikh Noah El-Qudha for Sharia and Law, The World Islamic \\ Science \& Education University, Amman, Jordan \\ Correspondence: Taha Atiyyat, Department of Comparative Law, Faculty of Sheikh Noah El-Qudha for Sharia and \\ Law, The World Islamic Science \& Education University, Amman, Jordan. E-mail: draliq130@gmail.com
}

Received: February 9, 2020

Accepted: June 13, 2020

Online Published: October 15, 2020

doi:10.5539/ilr.v9n1p100

URL: https://doi.org/10.5539/ilr.v9n1p100

\begin{abstract}
This paper investigates the impact of filing appeals on the parliamentary elections running the Hashemite Kingdom of Jordan. It, thus, aims to ensure free and fair elections governed by the justice and the transparency principles which pave the way for candidates and voters to appeal, if needed, during the parliamentary electoral process as considered one of the most important guarantees the legislator vouches for in the Election Law. In addition to the conclusion and recommendations, the study tackles the theme of parliamentary appeals from different perspectives: its definition and relation to legality principle; the role of courts in judging such sort of appeals; the criteria of this appeals and appellants; and the appeals in the parliamentary electoral polls; nomination, and membership validity.
\end{abstract}

Keywords: parliamentary elections, election law, appeal, electoral process, Jordan

\section{Introduction}

The citizens' awareness about their obligations and rights, abiding by constitutions and election laws, is considered a principal element in their interaction and affective involvement with the political, economic, and social realms. Being a member in the parliament election presents a vital example on the citizens' political rights they own as stipulated by constitutions globally. The participation in parliamentary elections becomes a milestone in the democratic society since it is considered consolidates the sense of statehood and reflect the most important features of the democratic system through allowing the states' citizens to exercise their rights and electing their political representatives. Henceforth, the election process is not an ultimate objective but rather a means of establishing democracy through which the societies will is known and the parliament's role is activated. Furthermore, this process enhances the legislative authority's role in the state's governance; i.e. it gives authority for the elective body to practice its constitutional defined tasks and safeguard the parliamentary electoral process in Jordan from the disadvantages that might be encountered. Accordingly, this study sheds the light on the main impact for appeals at during the parliamentary electoral process in Jordan.

\section{Statement of Problem}

The researcher attempts to discuss mainly the influence of appealing that might be encountered during the parliamentary elections in Jordan. The theme is investigated from the legality perspective in order to accomplish a parliament elected in accordance with the law provisions. Thus, the elections procedures are flawless and transparent with regard to the Election Law No. (16) for the year 2016. ${ }^{(1)}$

\section{Significance of the Study}

The significance of this study arises from the need to define the electoral parliamentary appeals in Jordan and the importance of a clarifying it's nature and legal impact on its practice. Consequently this study will add a pragmatic value to the scientific real in terms of the knowledge relevant to the parliamentary electoral process.

\section{Methodology}

In order to accomplishing the study objectives, the analysis will be based on the qualitative, descriptive method. Thus, a peculiar description of the concepts relevant to the parliamentary electoral appeals will be defined and investigated. 


\section{Review of Related Literature}

A body of research has discussed the issue of elections; many of them have been concerned with the parliamentary elections in general; however, a few studies have focused the attention on the electoral appeals.

AlAjarmah (2010) indicates to the extent of the judicial inspection on election appeals in Jordan, and it compares and contrasts between the administrative adjudication and the civil adjudication. Furthermore, Azzuaitar (2009) conducts a comparative study aiming at reviewing the primary procedures preceding the parliamentary elections in Jordan, compared to the American, French, Egyptian, and Lebanese legislations. The study investigates the procedures for the voter's registration in the electoral rolls, assignment of constituencies, and the censorship on the parliamentary elections procedures.

As for the judicial review on appeals, AlHarbi (2005) discusses the issue of electoral appeals and the validity of parliamentary electoral membership. Throughout his study, the researcher attempts to build up an analysis on the jurisdiction in relation to adjudication in election petitions and adjudication in the validity of parliamentary membership.

\section{Discussion}

\subsection{Parliamentary Electoral Appeals}

Elections are regarded as the fundamental element to participate in the political and democratic life. It is, thus, the cornerstone of boosting the citizens' sense of statehood and patriotism through gifting them with the legitimacy to exercise the power and right of issuing proper legislation deems necessary for the social development. For individuals, the electoral process provides the opportunity to them to practice their political power by enjoying their rights in their "democratic society". By doing so, this process is defined as the real participation in the decision-making process as its importance lies in giving the community the right and freedom to vote for the proper representative in the lower house through standardized competition.

\subsubsection{Parliamentary Electoral Appeals}

The parliamentary elections gain its importance by giving the community the entire freedom to vote for the proper representative in the lower house through standardized and transparent competition between the different political parties who seek to win the best status. Appeals and objections are allowed to be submitted during the whole parliamentary process for ensuring fee and transparent elections based on the transparency and justice principles. In this context, the process of appeal filing is not only regarded as the most principal method guaranteed by law to keen the elections transparent but also as the most important procedures to be allowed while encountering the erroneous electoral decisions. Consequently, these procedures must be simplified, and the decision related to such a process must be vital and effective in a way that they ensure security during the whole election process activities, such as: candidates" disputes, votes counting and results declaration, forged or incorrect data of election rolls, votes on the balanced, inaccurate electoral rolls, impersonating others to vote, and the lack of candidature, polling, sorting, and appealing against the candidates' membership with accordance to Articles $(4,15,16,19,40,44,53)$ stated in the Election Law No. 6 of 2016; Articles $(7,11,12,13,14,17,22)$ designed for candidates' rolling, candidature, polling, and sorting; and Article (71) in the Jordanian Constitution of 1952.

\subsubsection{Parliamentary Electoral Appeals Concept}

Some of the parliamentary elections procedures light arise disputes, especially when a candidate claims a problem. Henceforth, voting for candidates becomes a problematic and conflicting issue as then an individual might be puzzled before or during the process itself and during the voting process and the results declaration.

The lower house-related appeals, as a concept, are defined as disputes occurring as a result of the electoral procedures and results (Shawqi, 2009). Some of jurists have defined it from two scopes: the broad and the narrow. From the broad scope, it is denoted that parliamentary appeals involve any procedures or acts relevant to the election process, starting from defining or establishing constituencies until declaring the running results. On the other hand, the narrow-scoped definition is confined to the peculiar definition of the election process which indicates, then, appealing against voting and sorting procedures due to being exposed to flaws, fraud, physical coercion or abstract coercion (Shaqani, 2008).

Others indicate to such appeals as a sort of petitions submitted by a body of legal interest before specialized legal authorities in order to include or exclude candidates' names on the electoral rolls with accordance to law; or to appeal in the core committees' decisions in relation to the request of names' listing or deletion before judges, and the running results, polls, or appeals against the candidate's membership (Afifi, 1984). In this context, some researchers have focused the attention on the electoral appeals in the election results disputes created when results 
are claimed to have flaws, fraud, or coerced (Shaqawi, 2005). Furthermore, the Egyptian jurisdiction defines the electoral appeal as it is a sort of dispute due to the extent to which the election conveys in relation to the voter's will who question the validity of the polling and sorting processes which encounter cheating, forgery, coercion, and other obstacles (Abbadi, 2006).

According to the abovementioned definitions, the study concludes to that these appeals are a sort of petitions submitted by a stakeholder before the Independent Electoral Commission and the concerned courts to appeal in the validity of the entire election procedures. In addition, those appeals represent a group of objections submitted by the candidates or voters for the commission or the Court of Appeal and the First Instance Court because of the illegal faults happening during the electoral process.

\subsubsection{The Legality of Appeals in Parliamentary Election}

The parliamentary electoral appeals are regarded as one of the most important means that a stakeholder needs to object on any electoral stage. Thus, it is the right for the candidate or voter to submit objections during the primary the electoral stages, starting from the preparation of election-rolls stage and polls until the validity of membership stage. It is worthy to be noted that these appeals spawn a body of high-level voters and highly-efficient deputies. The Jordanian legislation asserts so as stipulated in Articles $(4,15,16,19,53$ in the Election Law No. 6 of 2016 related to the execution regulations of electoral rolls, candidature, polling and nomination and Article (71) in the Constitution stipulated in the validity of membership.

\subsubsection{The Judiciary Role in Parliamentary Electoral Appeals Review}

Generally speaking, the role of judiciary in the election process covers all its stages which commence by the polling and end by nomination. The researchers believe, in this context, that the electoral process is fruitful and purposeful because it is inspected by a specialized body whose members enjoying judicial immunity. Moreover, some constitutions stipulate the presence of judicial member in the committees formed to supervise the Parliamentary Electoral Process. Consequently, the judiciary system penetrates in the whole stages of the electoral process to ensure justice and transparency principles on one hand. On the other hand, many foreign constitutions highlighted such a role as the sole way for truthful competition and flawless nomination and results. It has taken a long time, however, to have this role from the theoretical zone into applications as stipulated in so-many constitutions. What has pushed this away to applicable grounds is the democratic wakeup which has prompted some countries to establish independent electoral commissions, with accordance to law, responsible for the entire supervision on the electoral process and express the community's opinions and will (AlBaz, 2006).

\subsection{Criteria of Parliamentary Electoral Appeals}

The electoral appeal is considered a right ensured by Constitution and law. Therefore, each voter listed his name on the election rills and candidates in a particular constituency have the right to appeal. Any or both of them have the right to submit petitions in the Independent Electoral Commission to appeal in front of the concerned courts where the commission is announcing the provisions against him. Whereas for the refusal to accept any announced provision, the voter or candidate submits an appeal during the legal period defined by law as these stakeholders are of interest or right. The appeal must be submitted by the appellant personally or by the one who is assigned an agent in case he owns legal accredited authorization authorizing him to submit the appeal. In addition, the appeal must include its causes and justifications as well as it must be written and signed by the appalent or the agent who has $a b=n$ accredited authorization of appealing (AlBaz, 2006).

Currently, the appealing right has gained high importance due to the systematic standardization it holds, which leads to achieving high degree of transparency and seriousness and other advantages or the candidates and voters during the election process, including all its stages supramentioned (Omar, 2006).

\subsubsection{Appealing against Electoral Polls}

The importance of creating electoral rolls is shown through its crystallized impact on accomplishing the election process objectives that reflect the parliamentary democratic system. Reviewing Article (4)/ paragraphs (G), (H/1,2), and $(\mathrm{I} / 2,3,4)$ in the Election Law No. 6 of 2016 and Articles $(7,8,12,13,17)$, it is found that the legislator allows for the voter whose data received a mistake or change or listed by others on the primary rolls of a constituency in his residency stay; to appeal in the Court of First Instance within seven days from the day following the decision issuance of the Civil Status Chamber to reject voting (Shatnawi, ...).

\subsubsection{Appeals against Nomination in Parliamentary Elections}

Historically speaking, the right of appealing in Jordan was eligibly confined to the nomination stage as evident in the Election Law of 1960 stating that it is the concern of the Supreme Court of Justice to consider appeals related 
to nomination, and the Election Law of 1986 stipulating that it is the concern of the Court of First Instance to decide on the appeals of the nominated, and these issued decisions are not subject to appealing before other bodies.

With reference to the Election Law No. 6 of 2016, it is found that the Jordanian legislator in Articles (6), (11/E/2), (16/A/2), and (19) sort to the Court of Appeal the duty of jurisdiction to review the candidates' appeals submitted thereafter the resolutions issuance of the Independent Election Commission Board which revises the nomination application within seven days from the day following the submission of nomination application. The Election Law grants the Board the right to reject the application once the cause is clarified. Also, it is the right for voters, candidates, or the Independent Election Commission Board to appeal against the approval or refusal of nomination application in front of the Court of Appeal located in the same constituency area within three days from the day following the notification date, noting that the courts resolution is definite as stipulated in Articles $(13,15)$ for the Implementing Regulations of 2016.

\subsubsection{Appealing against the Membership Validity}

No doubt that before the constitutional amendments of 2011 in Jordan, the Lower House was responsible exclus91ively for inspecting the membership validity in accordance with Article (71) of the Constitution (Note 1) which asserts this through submitting a petition to the Secretariat General of the Lower House including the legal reasons the appellant's membership validity identified by his name. The petitioner, or application, shall be submitted within fifteen days from the announcement date of election results. Also, the petitioner shall not reject any application submitted by a stakeholder provided that any decision related to this concern shall be by a vote of two-thirds of its members, and its decision is not subject to other bodies. Therefore, one of the must guarantees the constitutional amendment found has been the

assignment of those appeals to jurisdiction by submitting them before the Court of Appeal, located in the candidate's residency place, within fifteen days from the issuance date of election results in the official gazette.

With reference to Article (71) in the Jordanian Constitution and amendments of 2011 and Article (53) of the Election Law No.6 of 2016, it is ensured through the parliamentary majoring over minority the principle of nations soverinity which does not allow any individual to run for the House unless he abides by legal terms satisfying the principle of separation of power.

\section{Conclusion}

There is no doubt that the submission of appeals is regarded as a vital part of electoral procedures in which it contributes to establishing a neutrally elected parliament. Accordingly, the withdrawal of authority in the appeal relevant ot the membership validity as to be considered a dispute is the core concern of jurisdiction with accordance to (71) of the Constitution amended in 2011. Furthermore, it is considered the highly- power of the Independent Election Commission to inspect the primary objection on the electoral procedures. In addition, the judiciary system plays an initial role in reviewing the appeals related to such procedures, the matter which is ensured in the Election Law No. 6 of 2016.

\section{Recommendations}

1) The jurisdiction of appeals related t the parliamentary election is recommended to be the concern of the Administrative Court due to its function rather than the Court of First Instance or Appeal Court.

2) It is preferred to establish commission in the civil courts of all governorates to include judges in the Appeal Court whose main duty is to facilitate and accelerate the appeals procedures and thus reduces the burdens on the Appeal Court located in Amman, the capital of Jordan.

3) It is seen to increase the time durations defined in the latest issues Election Law, especially the duration of appeals review to be at least fifteen days from the day following the decision issuance in order to allow a large number of voters, candidates, and the stakeholders to submit related petitions.

\section{References}

Abbadi, M., \& Kashakesh, K. (2006). The stages of preparing the electoral voters' polls in Jordan.

Afifi, M. (1984). The election system in justice. Saed Rafat Library: Ein Shams University.

AlAjarmah, N. (n.d.). The Judicial Review on the Electoral Appeals in Jordan.

Albaz, D. (2006). The right of joining political life. The Universal Thought House: Alexandria.

Azzuaitar, R. (2009). The censorship on the parliamentary electoral pre-procedures: A comparative study.

Harbi, S. (2005). Electoral appeals and the review on parliamentary candidature validity. 
Hind, M. (2006). The parliamentary electoral disputes and membership criteria for Lower House. The Legal Books House: Egypt.

Omar, H. (2006). The electoral elections: an analytic study for the Egyptian Parliament elections. Annahdah Publisher.

Shaqani, A. (2005). The principle of judicial supervision on the public vote for the presedential, legal, and local elections. Tnta University.

Shatnawi, F. (n.d.). The Constitutional System in Jordan. Addustour Commercial Publications: Jordan.

Shawqi, T. (2009). Techniques for the electoral censorship in Algeria.

The Election Law for Parliament No. 6 of 2016.

The Implementing Regulations for the Election Law relevant to the voters' rolling, polling, voting, and sorting.

The Jordanian Constitution of 1952 and amendments.

\section{Note}

Note 1. The Jordanian Constitution of 1952 and amendments.

\section{Copyrights}

Copyright for this article is retained by the author(s), with first publication rights granted to the journal.

This is an open-access article distributed under the terms and conditions of the Creative Commons Attribution license (http://creativecommons.org/licenses/by/4.0/). 